\title{
INTRODUCTION: WRITING THE LIVES OF SOME EXTRAORDINARY POLYNESIAN WOMEN
}

\author{
PHYLLIS S. HERDA \\ University of Auckland
}

Conversations in the 1990s between the late Elizabeth Wood Ellem and myself about the portrayal of Pacific Island women in historical texts led us to contact a number of scholars, some of whose writings have resulted in this "special issue" on the lives of some extraordinary Polynesian women.

Those long ago conversations were prompted in particular by two volumes published in the 1970s and edited by historians at the Australian National University: Pacific Island Portraits (Davidson and Scarr 1970) and More Pacific Island Portraits (Scarr 1978). The 25 chapters in these two collections were equally balanced between indigenous and European subjects - including portraits of 24 significant individuals in the post-contact history of Oceania - but not a single woman. While the omission of women did not seem particularly notable in the 1970 s, some 20 years later it was remarkable. In addition the inclusion of Europeans is representative of the approach often adopted at the time the volumes were produced. Elizabeth and I felt that a book focused on Pacific Island women was long overdue. In considering such a collection in light of our own research on Tongan historical women (Herda 1987 and Wood Ellem 1999), we decided that a geographical focus on Polynesia, rather than the wider Pacific, would both be more manageable and give greater coherence to the volume.

Our intention was to represent a variety of notable women from Polynesia's past; not necessarily just those who rose to prominence through high birth rank. With this in mind, scholars with expertise in Polynesian studies and a concomitant interest in gender were approached about contributing to the volume. There was strong support for the project and each author selected the woman, or in some cases women, whose portrait they would create.

Traditional historical research into the lives and experiences of Polynesian women has been problematic owing to the absence or minimisation of women in the historical record. Early visiting Europeans, be they explorers, beachcombers, whalers or traders, were almost exclusively male. They expected to deal with male leaders and sought out contact with indigenous men. If contact was made with women, especially non-chiefly women, it was almost always sexual in nature. The journals and memoirs of these visitors reflect this androcentric bias. For example, the French expedition under the command of Bruni d'Entrecasteuax (Labillardiere 1800) which visited 
Tongatapu in 1793, met an influential woman whom they called "Queen Tineh" (probably Tu'i Tonga Fefine Nanasipau'u). Although they mention in passing her exalted rank and her undoubted authority, their substantive entries markedly focus on the exploits of male chiefs. While there are several named portrait sketches of Tongan men from the voyage, the only woman whose portrait was sketched is simply identified as "Woman of the Friendly Islands" in a coquettish pose suggesting sexual availability (Labillardiere 1800: 392). Similarly, male Christian missionaries, ardent chroniclers of Polynesia in the late 18th and 19th centuries, generally ignored the activities of non-chiefly women and censured the behaviour of politically active women of high birth rank as unfeminine or improper. The resulting archival records of Polynesia substantially focus on men and their activities as if they represented the entirety of society. Histories based on these sources consequently ignored or minimised the roles of women and more often than not misunderstood indigenous gender concepts. Women, if represented at all, were portrayed as sexual objects or as inept or unseemly rulers.

Elizabeth and I received a number of manuscripts detailing the lives of notable women, but changing circumstances and new research projects took both of us away from completing the volume at that time and it seemed that it would remain in limbo. However, recently Judith Huntsman, an editor of the Journal of the Polynesian Society, approached me about publishing some of the portraits as a special issue of the Journal. This seemed an excellent way to resurrect the project and to have at least some of the portraits in print and online. Judith and I read through the material and selected portraits which were both diverse and would make a cohesive Journal issue. The authors welcomed the chance, not just to bring their subject's life to an interested reading public, but also to consider how academia had changed from the project's inception.

Life and oral history and biographical narratives have proved to be a popular genre of both academic and general historical writing. They allow the voice of the subject to be heard in an individual and intimate interpretation of the past. They articulate conceptualisations of personhood or, in the case of this volume, womanhood and how that notion of womanhood is lived through diverse experiences and turning points in an individual's life. The narrative of a life also highlights significant relationships as it chronicles the passing of time and therefore also speaks about indigenous gender relations and how they transformed under colonialism. Oral and biographical research can also help to overcome the androcentric bias of surviving written archives.

The academic study of gender and the position of women in Polynesian society and history through biography have grown in prominence since the late 1970s and early 1980s. Biographical accounts of Māori women were 
published in Aotearoa/New Zealand early in that period. For example, the autobiography of Amiria Stirling (Stirling 1976), facilitated by Anne Salmond, related the life of a notable Māori woman. Similarly, Judith Binney and Gillian Chaplin (1986) employed oral history methods to research the lives of Māori women who were followers of Te Kooti and the Ringatu faith. The importance of genealogy (whakapapa) in the women's lives and Māori belief emerges as a central theme of the monograph.

The lives of several historically significant women in Island Polynesia were brought to scholarly attention when Caroline Ralston and Nicholas Thomas organised a session on gender in Polynesian history at the 1985 conference of the Pacific History Association held in Suva, Fiji. The five contributions considered women of high birth rank from several island groups and these were published in 1987 in two issues of the Journal of Pacific History. Two years later an influential collection of essays focused on family, gender and colonialism in the Pacific was published. Many of the chapters in that volume, edited by Margaret Jolly and Martha Macintyre (1989), were concerned with individual Pacific women.

The 1990s saw continued interest in studies of gender and the position of women in Polynesian history and society. High rank and political prominence were not necessary characteristics for a life to be considered worthy of being chronicled. Jocelyn Linnekin (1990), for example, portrayed the lives of nonchiefly or commoner Hawaiian women and men in the 18th and 19th centuries through the creative use of claimants' statements to the Land Commission, informed by a consideration of the rich Hawaiian ethnohistorical literature. Caroline Ralston's overview (1992a) examined how women in Polynesia and the larger Pacific region have been represented in history. Elizabeth Wood Ellem's (1999) biography of Queen Sālote of Tonga considered the life of this beloved monarch, through personal experiences and public events, in the 20th century history of Tonga. Māori and Island Polynesian women have also been included in collections of biographical sketches of women in Aotearoa/ New Zealand such as The Book of New Zealand Women (Macdonald, Penfold and Williams 1991), The Dictionary of New Zealand Biography (1990-2000), and Lyndon Fraser and Katie Pickles' collection of essays (2002) on women and migration in New Zealand history.

Biographies and life histories of Polynesian women for a more general readership also appeared at this time. Lynnsay Rongokea's $(1992,2001)$ volumes on Cook Island quilts (tivaevae) included biographical sketches and photographic portraits gathered from interviews with the quilt-makers. The resulting publications present the life stories of Cook Island women accompanied by photographs of the women with their tivaevae. Peggy 
Fairbairn-Dunlop (1996) edited a collection of informal life histories of Samoan women both in the islands and abroad. The life of Tupou Posesi Fanua of Tonga was published by Lois Webster (Fanua 1996). Her life history was based on taped oral history interviews.

The portraits presented here offer the life stories of eight women through six essays. A collated bibliography of references from all the essays is presented at the end of the collected chapters. We begin with two 19th century queens of chiefly rank, who were politically powerful. Vaekehu, portrayed by Carol Ivory, was a high ranking woman born in the Marquesas in 1823. She grew up at a time when many of the traditional Marquesan ways were still practised and experienced dramatic impacts on them during her lifetime. By the time of her death in 1901 Vaekehu had converted to Catholicism and indeed became a devout and pious member of the church. 'Aimata Pomare IV, portrayed by Karen Stevenson, lived in Tahiti at a time of major cultural, political, religious and social changes. She ascended the throne in 1827 and reigned for 50 years until 1877. Born before Tahiti became Christian or French, 'Aimata Pomare IV learned to negotiate, ultimately not successfully, both indigenous rivalries and competing foreign interests intent on colonial rule.

The Coe sisters Emma, later known as Queen Emma, and Phebe, known in New Guinea as "Miti", are portrayed by Damon Salesa. They bridge the 19th and 20th centuries. The sisters were born to a Samoan mother and an American father, and raised in Samoa in the latter half of the 19th century. Through advantageous marriages and astute business acumen the women attained fame and notoriety as they created a trading and planting empire in northern New Guinea during the late 19th and early 20th centuries, a time of tremendous upheavals in the colony.

All four of the women from the 20th century were, coincidentally, born in 1924 and all were revered for their service to their communities. Sister Tu'ifua, portrayed by Adrienne Kaeppler, a Tongan Catholic nun of the Sisters of the Society of Mary, laboured assiduously to improve the quality of life of poor Tongan women through employment, housing, education, health and traditional medicine. Kula, portrayed by Judith Huntsman, was born on the atoll of Fakaofo and became Tokelau's first qualified nurse. She worked tirelessly to promote healthcare throughout the atolls and was known as a woman of great skill and enormous compassion who delivered countless healthy babies and provided much needed medical attention during her career. Nua, also portrayed by Judith Huntsman, was born on the Tokelau atoll of Atafu. She spent her early life in the atoll with her grandparents and then was sent to school in Samoa where her father worked. Nua qualified as a teacher and was a pioneer in establishing the modern education system in Tokelau. Whāea Betty Wark, portrayed by Helene Connor, was born in the Hokianga, 
Aotearoa/New Zealand. "Ma Betty", as she was affectionately known, was a much loved and respected community worker. Her work among homeless children and young adults in central Auckland from the 1970s lead her to establish the Arohanui Trust to provide for those living in poverty. All four of these women were well known by their biographers who had spent many hours talking with them.

Much has changed in Polynesia and the wider Pacific during the lives of the women portrayed in these essays and this is reflected in how each of the portraits was researched and written. Ivory and Stevenson are both art historians. They worked with surviving documentary material to uncover and appreciate the lives of Vaekehu and 'Aimata. That both were high-ranking, powerful women is no accident. Early European chroniclers of the Pacific focused on women of rank whom they often identified as "queens". This, of course, reflected their understanding of what kind of women held positions of authority in their own society, as well as indicating who was considered notable or extraordinary in 19th century Polynesia.

The authors of the 20th century portraits employed different methodologies in researching their subjects. Kaeppler and Huntsman are both cultural/social anthropologists who met Sister Tu'ifua (Kaeppler), Kula and Nua (Huntsman) while undertaking fieldwork in Tonga and Tokelau respectively. Both knew their subjects well and had a deep understanding of the women's cultures before writing their biographical sketches. This understanding enabled them to position each woman's achievements in the context of the time and societies in which they lived. In addition the egalitarian nature of Tokelauan society provides a contrast to the marked hierarchy of the other represented island groups. Connor's academic degree is in Women's Studies and she brings that discipline's approach of presenting a woman's life in her own words to her portrait of Betty Wark, who had sought out a biographer to chronicle her life. Connor met and grew to know Betty well through the biographical process. These women of the 20th century were deemed remarkable and extraordinary because of the service they brought to local communities rather than the circumstances of their birth.

Salesa, a historian, bridges the 19th and 20th centuries in his portraits of Emma and Phebe (Miti) Coe. This bridging was not just in the dates of women's lives, but also in terms of how their lives were appraised and recorded. Queen Emma, as she was known, emphasised her American heritage, through her father, when negotiating her marriages and position within society. However, her notoriety, during her lifetime and as chronicled by her biographers (Banas 1988, Dutton 1976, Grove-Day 1969, Robson 1965) relied heavily on a romantic construction of a sexualised, exotic Polynesian woman. Her sister, Miti, by contrast, identified with her Samoan 
side through her mother's ancestry. She was recognised as having a keen intellect and an exceptional understanding of local New Guinean customs and language. Miti's biographers Mead (1960) and Overell (1923), unlike Emma's, knew her well. Mead also corresponded extensively with Miti and both biographers sought to contextualise Miti's life within her community.

Our primary goal in assembling these portraits has been to highlight the lives and experiences of Polynesian women in history who have not always been included in the historical record and to create an understanding of wider social history as expressed through the lives of prominent women. Each portrait adopts an intimate focus on the life of its subject. Although in different times and archipelagos all of the portraits demonstrate the importance of family, ancestry, church and community to the women's lives as well as the major political, religious and social transformations which occurred as European colonialism and Christianity came to the region. In addition many of the women's experiences embrace issues of modernity such as advanced education, employment, migration and transnationalism. All of the authors have an intimate knowledge of indigenous history, society and culture which underpins their depiction of their subjects. In addition, all are passionate about the islands they work in and the people who inhabit those islands. The result is a rich and accessible collection of biographical sketches of extraordinary Polynesian women.

\begin{abstract}
This "special issue" on the lives of some extraordinary Polynesian women considers biographical narrative as a means of highlighting the lives and experiences of Polynesian women in history and creating an understanding of wider social history. Traditional historical research into the lives and experiences of Polynesia usually ignored or minimised women in the historical record. Indigenous gender concepts were usually misunderstood and women, if represented at all, were portrayed as sexual objects or as inept or unseemly rulers. Allowing the voice of the subject to be heard, instead, permits an individual and intimate as well as culturally rich interpretation of the past.
\end{abstract}

Keywords: women, gender, life history, biography

Author contact address: Dr Phyllis Herda, Department of Anthropology, University of Auckland, Private Bag 92012, Auckland, New Zealand. Email: p.herda@auckland.ac.nz 